\title{
HIV Viral Load Measurement
}

National Cancer Institute

\section{Source}

National Cancer Institute. HIV Viral Load Measurement. NCI Thesaurus. Code C92544.

The determination of the HIV viral load in a specimen. 